\title{
Antimicrobial and antiparasitic abietane diterpenoids from Cupressus sempervirens
}

This article was published in the following Dove Press journal:

Research and Reports in Medicinal Chemistry

13 April 2012

Number of times this article has been viewed

\author{
Jin Zhang',2 \\ Aziz A Rahman ${ }^{3}$ \\ Surendra Jain' \\ Melissa R Jacob' \\ Shabana I Khan ${ }^{1,4}$ \\ Babu L Tekwani',5 \\ Muhammad Ilias' \\ 'National Center for Natural \\ Products Research, ${ }^{2}$ Institute of \\ Medicinal Plant Development, Chinese \\ Academy of Medical Sciences, \\ Peking Union Medical College, \\ Beijing, People's Republic of China; \\ ${ }^{3}$ Department of Pharmacy, University \\ of Rajshahi, Rajshahi, Bangladesh; \\ ${ }^{4}$ Department of Pharmacognosy, \\ ${ }^{5}$ Department of Pharmacology, \\ Research Institute of Pharmaceutical \\ Sciences, School of Pharmacy, \\ University of Mississippi, \\ University, MS, USA
}

\begin{abstract}
Cupressus sempervirens L. (Cupressaceae) is a species of cypress native to the eastern Mediterranean region. The ethanol extract of the powdered cones (fruits) of this plant, collected from Oxford, Mississippi during the fall of 2010, exhibited potent antimicrobial and antiparasitic activities. Bioassay-guided fractionation using a centrifugal preparative thin-layer chromatography yielded two potent antileishmanial and antimicrobial diterpenes, 6-deoxytaxodione (11-hydroxy-7, 9(11), 13-abietatrien-12-one) (1) and taxodione (2), together with ferruginol (3) and sugiol (4). Compounds 1 and 2 displayed potent antileishmanial activity with half-maximal inhibitory concentration $\left(\mathrm{IC}_{50}\right)$ values of $0.077 \mu \mathrm{g} / \mathrm{mL}$ and $0.025 \mu \mathrm{g} / \mathrm{mL}$, respectively, against Leishmania donovani promastigotes, compared to those of the standard antileishmanial drugs, pentamidine $\left(\mathrm{IC}_{50} 1.62 \mu \mathrm{g} / \mathrm{mL}\right)$ and amphotericin B $\left(\mathrm{IC}_{50} 0.11 \mu \mathrm{g} / \mathrm{mL}\right)$. Compounds $1-3$ were also evaluated against $L$. donovani amastigotes in THP1 macrophage cultures. In addition, both 1 and 2 showed potent antibacterial activities $\left(\mathrm{IC}_{50} 0.80\right.$ and $0.85 \mu \mathrm{g} / \mathrm{mL}$ ) against methicillin-resistant Staphylococcus aureus. Compounds 1 and 2 had previously been isolated from Clerodendrum eriophyllum, where 2 showed potent cytotoxic activity. However, this is the first report of antimicrobial and antileishmanial activities of compound 1 .
\end{abstract}

Keywords: Cupressus sempervirens, abietane diterpene, 6-deoxytaxodione, taxodione, antimicrobial, antiparasitic

\section{Introduction}

Cupressus sempervirens L. (Cupressaceae), the Mediterranean Cypress (also known as Italian, Tuscan, or Graveyard Cypress, or Pencil Pine) is a species of cypress native to the eastern Mediterranean region, northeast Libya, southeast Greece (Crete, Rhodes), southern Turkey, Cyprus, northern Egypt, western Syria, Lebanon, Israel, Malta, Italy, western Jordan, and also a large indigenous population in Iran. This plant is naturalized in the USA and has been widely cultivated as an ornamental tree. ${ }^{1}$

C. sempervirens has been traditionally used for the treatment of cold, flu, sore throat and rheumatism. ${ }^{2}$ The branches of this plant are used as antiseptics and antispasmodics. ${ }^{3}$ Phytopreparation obtained from the cores and young branches of $C$. sempervirens was reported to have antiseptic, aromatherapeutic, astringent, balsamic and antiinflammatory activities. Abietane diterpenoids have been isolated from the fruits of $C$. sempervirens and were evaluated for their inhibitory activity against glycogen phosphorylase and glucose-6-phosphatase enzymes. ${ }^{4}$

Leishmaniasis is an important tropical vector-borne disease that causes considerable mortality throughout the world. Visceral leishmaniasis, caused by Leishmania donovani, is a severe form in which the parasites have migrated to the vital organs.
Correspondence: Muhammad llias PO Box 3057, University of Mississippi, University, MS, 38677, USA

Tel +6629 I5 I05I

Fax +6629157989

Email milias@olemiss.edu
Research and Reports in Medicinal Chemistry 2012:2 I-6

(C) 2012 Zhang et al, publisher and licensee Dove Medical Press Ltd. This is an Open Access article which permits unrestricted noncommercial use, provided the original work is properly cited.
Dovepress

http://dx.doi.org// 0.2147/RRMC.S29902 
Approximately 350 million people live in the areas where Leishmaniasis can be transmitted. It affects as many as 12 million people worldwide, with 1.5-2 million new cases each year. ${ }^{5}$ However, the current treatment regimens for this parasite are limited and are not ideal, as they are often associated with severe side effects and resistant strains of the parasite have developed. The second-line drugs, amphotericin B and pentamidine, show high toxicity at their effective therapeutic doses. Also, during the treatment for visceral or mucocutaneous leishmaniasis, parasites become resistant to the current treatment therapies of antimony or amphotericin B in many parts of the world, ${ }^{6,7}$ hence the search for new, safe and easy-to-administer drugs remains a top priority.

In our search for antiparasitic and antimicrobial compounds from natural resources, we found the ethanol extract of cones of $C$. sempervirens displayed significant activity against Leishmania donovani promastigotes, hence this plant was investigated further. In this paper we report the isolation of four known abietane diterpenoids, 6-deoxytaxodione (1), taxodione (2), ferruginol (3), and sugiol (4), according to the bioassay-guided fractionation using a centrifugal preparative thin-layer chromatography (CPTLC; Chromatotron ${ }^{\circledR}$; Harrison Research, Palo Alto, CA), as well as their antileishmanial, antimalarial, and antimicrobial activities.

\section{Materials and methods General procedure}

Proton nuclear magnetic resonance imaging $\left({ }^{1} \mathrm{H}-\mathrm{NMR}\right)$ spectra at $400 \mathrm{MHz}$ and carbon-13 NMR $\left({ }^{13} \mathrm{C}-\mathrm{NMR}\right)$ spectra at $100 \mathrm{MHz}$ were recorded on a Varian Mercury 400 spectrometer (Varian Inc, Palo Alto, CA). Analytical TLC was carried out on factory precoated silica gel $60 \mathrm{~F}_{254}$ plates (EMD Chemicals Inc, Darmstadt, Germany). Spots were visualized by observing under UV light at $254 \mathrm{~nm}$ or $365 \mathrm{~nm}$ and spraying with $10 \% \mathrm{H}_{2} \mathrm{SO}_{4}-\mathrm{MeOH}$ reagent followed by heating. CPTLC (Chromatotron ${ }^{\circledR}$ model 8924, tagged with a fraction collector; Harrison Research) was carried out on $1 \mathrm{~mm}$ silica gel rotor (coated with $\mathrm{F}_{254}$ indicator; Analtech, Newark, DE). The samples were dried using a Savant Speed Vac Plus SC210A concentrator (Savant Instruments, Farmingdale, NY).

\section{Drugs and chemicals}

For column chromatography (CC), silica gel (32-63 mesh; Merck, Darmstadt, Germany) was used as stationary phases. Certified solvents $(\mathrm{MeOH}$, hexane, EtOAc, etc; Fisher Chemical, Fairlawn, NJ) were used as mobile phases for CPTLC and CC. Samples were dissolved in $\mathrm{CDCl}_{3}$ solution (Cambridge Isotope Laboratories, Andover, MA) for one-dimensional (1D) and 2D NMR using the residual solvent as the international standard. Ciprofloxacin $(99.3 \%$ purity; ICN Biomedicals, Aurora, $\mathrm{OH}$ ) for bacteria and amphotericin B (94.8\% purity; ICN Biomedicals) for fungi were used as drug controls in antimicrobial assay. Pentamidine and amphotericin B (Sigma-Aldrich, St Louis, MO) were used as standard antileishmanial agents. Chloroquine and artemisinin (Sigma-Aldrich) were used as drug controls in the antimalarial assay.

\section{Plant materials}

A sample of the fruits (cones) of this plant was collected from Oxford, Mississippi during the fall of 2010 and identified by Dr Vijayasankar Raman, National Center of Natural Product Research (NCNPR), University of Mississippi.

\section{Extraction and isolation}

The dried, powdered cones (63 g) were extracted by percolation with $95 \% \mathrm{EtOH}(1 \mathrm{~L} \times$ seven times $)$ and the combined extracts were concentrated to dryness using a rotary evaporator at $45^{\circ} \mathrm{C}$. The dried exact was subjected to biological assay for antileishmanial, antimalarial, and antimicrobial activities at NCNPR and showed good activities. Therefore, the dried crude extract (9 g) was subjected to bioassay-guided fractionation using silica gel column (32-63 mesh, 270 g silica; Merck) with gradient elution of $n$-hexane-EtOAc (99:1-50:50). Fractions were collected in $100 \mathrm{~mL}$ aliquots and were combined to yield 27 fractions based on TLC analysis. Fraction 5 (84 mg), which showed good activities in biological assay, was further purified using CPTLC (Chromatotron ${ }^{\circledR}, 1 \mathrm{~mm}$ silica rotor) with $n$-hexane-acetone (99.5:0.5) to afford 6-deoxytaxodione $(1,4.8 \mathrm{mg})$ from subfraction $21-26$, taxodione $(2,6.7 \mathrm{mg})$ from sub-fraction 30-33, and ferruginol (3, $43.6 \mathrm{mg})$ from subfraction 37-45. On the other hand, sugiol (4, $49 \mathrm{mg})$ was crystallized from fraction 20 (208 $\mathrm{mg})$.

\section{Antileishmanial assay}

The in vitro antileishmanial assay was done on a culture of L. donovani promastigotes by Alamar Blue assay, which is designed to measure quantitatively the proliferation of various human and animal cell lines, bacteria and fungi. ${ }^{8}$ In a 96-well microplate the samples with appropriate dilution were added to the Leishmania promastigotes culture $\left(2 \times 10^{6}\right.$ cells $\left./ \mathrm{mL}\right)$ to get the final concentrations of $80 \mu \mathrm{g} / \mathrm{mL}$. The plates were incubated at $26^{\circ} \mathrm{C}$ for 72 hours and growth 
was determined. Pentamidine and amphotericin B were used as standard antileishmanial agents. Half-maximal inhibitory concentration $\left(\mathrm{IC}_{50}\right)$ values for each compound were computed from the growth-inhibition curve.

\section{In vitro macrophage amastigote assay}

A recently developed promastigote rescue assay was used. ${ }^{9}$ The THP1 cells (human acute monocytic leukemia cell line) were maintained in RPMI-1640 medium supplemented with $10 \%$ fetal bovine serum (FBS). The cells were prepared prior to each assay and suspended in RPMI-1640 medium with $10 \%$ FBS at a cell density of $2.5 \times 10^{5}$ cells $/ \mathrm{mL}$. Phorbol 12-myristate 13-acetate (PMA) was added to the cell suspension to achieve final concentration of $25 \mathrm{ng} / \mathrm{mL}$ and cells were seeded onto a clear flat-bottom 96-well plate with $200 \mu \mathrm{L}\left(5 \times 10^{4}\right.$ cells $)$ into each well. The plate was incubated in a $5 \% \mathrm{CO}_{2}$ incubator at $37^{\circ} \mathrm{C}$ for at least 12 hours for differentiation of the THP1 cells to adherent macrophages. After overnight incubation the medium from each well was discarded and adherent cells were gently washed at least twice with serum-free RPMI-1640 medium. The Leishmania donovani promastigotes culture was harvested at the stationary phase (metacyclic infective stage) and suspended into RPMI-1640 medium with $2 \%$ FBS at the density of $2.5 \times 10^{6}$ cells $/ \mathrm{mL}$. The $200 \mu \mathrm{L}$ of promastigotes $\left(5 \times 10^{5}\right.$ cells $\left./ \mathrm{mL}\right)$ culture was added to each well. The plate was further incubated in a $5 \% \mathrm{CO}_{2}$ incubator at $37^{\circ} \mathrm{C}$ for at least 24 hours to allow infection of macrophages with the Leishmania parasites. After 24 hours the nonadherent macrophages and unattached Leishmania promastigotes were washed off with serum free RPMI-1640 medium. The infected macrophages were further incubated at $37^{\circ} \mathrm{C}$ and $5 \% \mathrm{CO}_{2}$ in $200 \mu \mathrm{L}$ RMPI1640 medium and 2\% FBS with different concentrations of standard antileishmanial drugs (pentamidine and amphotericin B) or the test compounds for 48 hours. The control wells with medium, uninfected THP1 cells, infected cells without drugs or test compounds were also set up simultaneously. The cultures were washed off with serum-free RPMI-1640 and treated for 30 seconds with $20 \mu \mathrm{L}$ of $0.05 \%$ sodium dodecyl sulfate in RPMI1640 medium for the release of amastigotes from the infected macrophages. To each well, $180 \mu \mathrm{L}$ of RPMI-1640 medium with $10 \%$ FBS was added and the plate was further incubated at $26^{\circ} \mathrm{C}$ for 48 hours to allow transformation of released amastigotes to promastigotes. To each well, 20 $\mu \mathrm{L}$ of Alamar blue was added, the plates were incubated at<smiles>CC(C)C1=CC2=CCC3C(C)(C)CCC[C@@]3(C)C2=C(O)C1=O</smiles>

\section{1 (6-deoxytaxodione)}

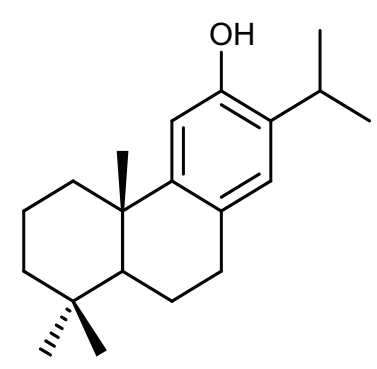

3 (ferruginol)<smiles>CC(C)C1=CC2=CC(=O)C3C(C)(C)CCC[C@]3(C)C2=C(O)C1=O</smiles>

2 (taxodione)<smiles>CC(C)c1cc2c(cc1O)[C@]1(C)CCCC(C)(C)C1CC2=O</smiles>

4 (sugiol)

Figure I Structures of compounds isolated from $C$. sempervirens $L$. 
Table I Antileishmanial activity $\left(\mathrm{IC}_{50} / \mathrm{IC}_{90}\right.$ in $\left.\mu \mathrm{g} / \mathrm{mL}\right)$ of extract, fractions, and abietane diterpenes isolated from $C$. sempervirens

\begin{tabular}{|c|c|c|c|c|c|c|}
\hline \multirow[t]{3}{*}{ Extract/compound } & \multicolumn{4}{|c|}{ Leishmania donovani } & \multirow{2}{*}{\multicolumn{2}{|c|}{$\begin{array}{l}\text { Cytotoxicity } \\
\text { (transformed } \\
\text { THPI cells) }\end{array}$}} \\
\hline & \multicolumn{2}{|c|}{ Promastigotes } & \multicolumn{2}{|c|}{ Macrophage amastigotes } & & \\
\hline & $\mathrm{IC}_{50}$ & $I C_{90}$ & $I_{50}$ & $I C_{90}$ & $\mathrm{IC}_{50}$ & $I_{90}$ \\
\hline C. sempervirens & 0.65 & 1.13 & NT & NT & NT & NT \\
\hline \multicolumn{7}{|l|}{$\mathrm{EtOH}$ extract } \\
\hline Fraction 5 & 0.405 & 0.560 & 1.97 & 5.91 & 7.31 & 9.24 \\
\hline Fraction 20 & $>40$ & $>40$ & NT & NT & NT & NT \\
\hline I & 0.077 & 0.196 & 2.72 & 3.14 & $>10$ & $>10$ \\
\hline 2 & 0.025 & 0.056 & 5.40 & $>10$ & $>10$ & $>10$ \\
\hline 3 & NT & NT & 2.36 & 3.15 & 5.79 & 7.39 \\
\hline 4 & NT & NT & $>10$ & $>10$ & $>10$ & $>10$ \\
\hline Pentamidine & 1.62 & 2.10 & $2.39-2.74$ & $4 .|8-5.4|$ & $>10$ & $>10$ \\
\hline Amphotericin B & 0.11 & 0.19 & $0.15-1.09$ & $0.31-1.96$ & $>10$ & $>10$ \\
\hline
\end{tabular}

Abbreviations: $\mathrm{IC}_{50}$, half-maximal inhibitory concentration; $\mathrm{IC}_{9}$, inhibitory concentration of $90 \%$; NT, not tested.

$26^{\circ} \mathrm{C}$ for 24 hours and read on a BMG Fluostar micropate reader (BMG Lab Technologies, Durham, NC) at excitation wavelength of $544 \mathrm{~nm}$ and emission wavelength of $590 \mathrm{~nm}$. Each compound was tested in duplicate at six concentrations; $\mathrm{IC}_{50}$ and $\mathrm{IC}_{90}$ values were computed from the dose response curves.

\section{Antimalarial assay}

The in vitro antiplasmodial activity was measured by a colorimetric assay that determines the parasitic lactate dehydrogenase (pLDH) activity. ${ }^{10}$ The assay was performed in a 96-well microplate and included two Plasmodium falciparum clones (Sierra Leone D6 [chloroquine-sensitive] and Indochina W2 [chloroquine-resistant]; Walter Reed Army Institute of Research, Silver Spring, MD). For the assay, a suspension of red blood cells infected with $P$. falciparum (D6 or W2) strains (200 $\mu \mathrm{L}$, with 2\% parasitemia and 2\% hematocrit in RPMI-1640 medium supplemented with $10 \%$ human serum and $60 \mu \mathrm{g} / \mathrm{mL}$ amikacin) was added to the wells of a 96-well plate containing $10 \mu \mathrm{L}$ of test samples at various concentrations. The plate was flushed with a gas mixture of $90 \% \mathrm{~N}_{2}, 5 \% \mathrm{O}_{2}$, and $5 \% \mathrm{CO}_{2}$ in a modular incubation chamber (4464 M; Billups-Rothenberg, San Diego, CA) and incubated at $37^{\circ} \mathrm{C}$ for 72 hours. Plasmodial LDH activity was determined by using Malstat reagent (Flow Inc, Portland, OR) as described earlier. ${ }^{10}$ The $\mathrm{IC}_{50}$ values were computed from the dose-response curves generated by plotting percent growth against test concentrations. Dimethyl sulfoxide $(0.25 \%)$, artemisinin, and chloroquine were included in each assay as vehicle and drug controls, respectively. The selectivity indices (SI) were determined by measuring the cytotoxicity of samples toward mammalian cells (Vero; monkey kidney fibroblast). All experiments were carried out in duplicate.

\section{Antimicrobial assay}

All microorganisms were obtained from the American Type Culture Collection (ATCC, Manassas, VA) and include the fungi Candida albicans (ATCC 90028), C. krusei (ATCC 6258), C. glabrata (ATCC 90030), Cryptococcus neoformans (ATCC 90113), Aspergillus fumigatus (ATCC 204305), and the methicillin-resistant bacterium Staphylococcus aureus (MRSA; ATCC 33591). ${ }^{11,12} \mathrm{IC}_{50}$ relative to controls were calculated using XL fit 4.2 software (IDBS, Alameda, CA) using fit model 201 based on duplicate readings. Drug controls [Ciprofloxacin (99.3\% purity; ICN Biomedicals) for bacteria and amphotericin B (94.8\% purity; ICN Biomedicals) for fungi] were included in each assay.

\section{Results and discussion}

A bioassay-guided fractionation, followed by repeated purification using centrifugal preparative TLC of the

Table 2 Antimalarial activities of $C$. sempervirens extract, fractions, compounds I and 2

\begin{tabular}{|c|c|c|c|c|c|}
\hline \multirow{3}{*}{$\begin{array}{l}\text { Extract/ } \\
\text { compound }\end{array}$} & \multicolumn{4}{|c|}{ P. falciparum $(\mu \mathrm{g} / \mathrm{mL})$} & \multirow{3}{*}{$\begin{array}{l}\text { Vero } \\
(\mu \mathrm{g} / \mathrm{mL}) \\
\mathrm{TC}_{50}\end{array}$} \\
\hline & \multicolumn{2}{|l|}{ D6 $^{a}$} & \multicolumn{2}{|l|}{$W 2^{b}$} & \\
\hline & $I_{50}$ & $\mathbf{S I ^ { c }}$ & $I C_{50}$ & $\mathbf{S I}{ }^{\mathrm{c}}$ & \\
\hline C. sempervirens & 2.9 & 10.3 & 3.2 & 9.4 & 30 \\
\hline \multicolumn{6}{|l|}{$\mathrm{EtOH}$ extract } \\
\hline Fraction 5 & 2.7 & $>1.8$ & 1.7 & $>2.8$ & $\mathrm{NC}$ \\
\hline I & 3.0 & $>1.8$ & 2.8 & $>1.7$ & NC \\
\hline 2 & 2.6 & $>1.8$ & 1.9 & $>2.5$ & $\mathrm{NC}$ \\
\hline Chloroquine & 0.02 & & 0.15 & & NC \\
\hline Artemisinin & 0.005 & & 0.002 & & NC \\
\hline
\end{tabular}

Notes: ${ }^{\mathrm{a} C h l o r o q u i n e-s e n s i t i v e ~ c l o n e ; ~}{ }^{\mathrm{b}}$ chloroquine-resistant clone; ' selectivity index = $\mathrm{IC}_{50}$ VERO cells $/ \mathrm{IC}$. P. falciparum.

Abbreviations: NC, not cytotoxic (up to the maximum dose tested; $4.7 \mu \mathrm{g} / \mathrm{mL}$ for pure compounds and $47.6 \mu \mathrm{g} / \mathrm{mL}$ for crude extract and column fractions); $\mathrm{SI}$, Selectivity Index; $\mathrm{TC}_{50}$, median toxic concentration. 
Table 3 Antimicrobial activity of $C$. sempervirens extract, fractions, compounds $I$ and 2

\begin{tabular}{|c|c|c|c|c|c|c|}
\hline \multirow{3}{*}{$\begin{array}{l}\text { Organisms for } \\
\text { antimicrobial test }\end{array}$} & \multicolumn{6}{|c|}{$\mathrm{IC}_{50}(\mu \mathrm{g} / \mathrm{mL})$ of extract/compound } \\
\hline & C. sempervirens & Fraction 5 & I & 2 & Amphotericin B & Ciprofloxacin \\
\hline & \multicolumn{6}{|l|}{ EtOH extract } \\
\hline C. albicans & - & - & - & 4.47 & 0.17 & NT \\
\hline C. glabrata & - & 20.00 & 2.21 & $<0.8$ & 0.24 & NT \\
\hline C. krusei & - & - & 7.66 & 3.10 & 0.68 & NT \\
\hline A. fumigatus & - & - & 16.18 & 3.94 & 0.73 & NT \\
\hline C. neoformans & 3.71 & 4.65 & 1.85 & $<0.8$ & 0.36 & NT \\
\hline S. aureus & 12.48 & 1.70 & 1.34 & 0.80 & NT & 0.11 \\
\hline MRSA & 11.45 & 1.66 & 0.85 & 0.80 & NT & 0.10 \\
\hline M. intracellulare & - & 18.26 & - & 20.00 & NT & 0.30 \\
\hline
\end{tabular}

Abbreviations: -, not active; MRSA, methicillin-resistant Staphylococcus aureus; NT, not tested.

EtOH extract of C. sempervirens gave compounds 1-4, of which 1 and 2 displayed potent antileishmanial and antimicrobial activities. The molecular formulas of the two actives, 1 and 2, were established as $\mathrm{C}_{20} \mathrm{H}_{28} \mathrm{O}_{2}$ and $\mathrm{C}_{20} \mathrm{H}_{26} \mathrm{O}_{3}$ (calculated $\mathrm{m} / \mathrm{z} 301.21$ and $\mathrm{m} / \mathrm{z} 314.19$ ) from molecular ions $\mathrm{m} / \mathrm{z}$ 301.2326[M+H] and $\mathrm{m} / \mathrm{z}$ 315.2117[M + H]/ $332.3481\left[\mathrm{M}+\mathrm{NH}_{4}\right]$, respectively, by electrospray ionizationhigh-resolution mass spectroscopy. The abietane carbon skeletons of all the four compounds (1-4) were established, and complete structures were identified by ${ }^{1} \mathrm{H}$ and ${ }^{13} \mathrm{C} \mathrm{NMR}$, together with 2D NMR spectral experiments. The NMR spectral data of compound 1-4 were in agreement with those reported previously for 11-hydroxy-7, 9 (11), 13-abietatrien12-one, taxodione, ferruginol and sugiol, respectively. ${ }^{13-17}$ Compound 1 was named as 6-deoxytaxodione (Figure 1).

Compounds 1 and 2 displayed potent antileishmanial activity with $\mathrm{IC}_{50}$ values of $0.077 \mu \mathrm{g} / \mathrm{mL}$ and $0.025 \mu \mathrm{g} / \mathrm{mL}$, respectively, against $L$. donovani promastigotes. Compound 2 was found to be $>64$ - and $>4$.4-fold more potent than those observed for the standard antileishmanial drugs, pentamidine $\left(\mathrm{IC}_{50} 1.62 \mu \mathrm{g} / \mathrm{mL}\right)$ and amphotericin B ( $\left.\mathrm{IC}_{50} 0.11 \mu \mathrm{g} / \mathrm{mL}\right)$, respectively, while compound 1 was $>21$ - and $>1$.4-fold potent than these standards. Compounds 1-3 were also evaluated against $L$. donovani amastigotes in THP1 macrophage cultures and only 3 showed cytotoxicity towards transformed THP1 cells (Table 1), which was equipotent to pentamidine. However, compound 1 demonstrated the best activity without any cytotoxicity against THP1 cells. The weak antimalarial activities of compounds 1 and 2 against $P$. falciparum D6 and W2 strains were attributed by low $\mathrm{IC}_{50}$ values of $1.9-3.0 \mu \mathrm{g} / \mathrm{mL}$, compared with standard drugs of chloroquine and artemisinin (Table 2).

Among all the compounds, the antimicrobial activity was strongly displayed by compound 2 against $C$. albicans, C. glabrata, C. krusei, A. fumigatus, C. neoformans, S. aureus,
MRSA, and Mycobacterium intracellulare. Compound 2 showed potent inhibition against $C$. glabrata and $C$. neoformans with $\mathrm{IC}_{50}$ values $<0.8 \mu \mathrm{g} / \mathrm{mL}$ compared to the $\mathrm{IC}_{50}$ values of $0.24 \mu \mathrm{g} / \mathrm{mL}$ and $0.36 \mu \mathrm{g} / \mathrm{mL}$ of standard drug amphotericin B, respectively. Compound 1 was generally weakly active compared to 2 against most of these organisms, except MRSA where the $\mathrm{IC}_{50}$ value was found to be $0.85 \mu \mathrm{g} / \mathrm{mL}$ (Table 3).

All four compounds had previously been isolated from Clerodendrum eriophyllum (Fabaceae), a plant collected from Kenya, where compound 2 showed potent cytotoxic activity. ${ }^{17}$ However, this appears to be the first report of compounds 1 and 2 from the C. sempervirens, and also this is the first report of antimicrobial and antileishmanial activity of compound 1 .

\section{Acknowledgments}

The authors sincerely thank Dr Vijayasankar Raman, Dr Bharathi Avula, Ms Marsha A Wright and Mr John Trott from the University of Mississippi for plant identification, recording mass spectra, antimicrobial assay, and antimalarial assay, respectively. This work is supported by US Department of Defense CDMRP grant \#W81XWH-09, in part by the USDA Agricultural Research Service Specific Cooperative Agreement No 58-6408-2-0009 and the NIH, NIAID, Division of AIDS, Grant No AI 27094.

\section{Disclosure}

The authors report no conflicts of interest in this work.

\section{References}

1. Conifer Specialist Group. Cupressus sempervirens. 2006. IUCN Red List of Threatened Species. IUCN 2006. Available from: http://www. iucnredlist.org. Retrieved on May 11, 2006.

2. Larousse L, editor. Encyclopédie des Plantes Médicinales: Identification, préparations, soins. [Encyclopedia of Medicinal Plants: Identification, preparations, treatments]. Paris, France; Larousse; 2001:14-29.

3. Bellakhder J. La Pharmacopée Marocaine Traditionnelle. Paris, France: Edition Ibis Press; 1997:272-274. 
4. Preeti R, Mohammad FK, Manmeet K, et al. Constituents from fruits of Cupressus sempervirens. Fitoterapia. 2010;81(3):162-166.

5. Desjeux P. Leishmaniasis: current situation and new perspectives. Comp Immunol Microbiol Infect Dis. 2004;27(5):305-318.

6. Soto J, Toledo JT. Oral miltefosine to treat new world cutaneous leishmaniasis. Lancet Infect Dis. 2007;7(1):7.

7. World Community Grid. Drug search for leishmaniasis. Available from: http://www.worldcommunitygrid.org/research/dsfl/overview.do. Accessed on Jan 31, 2012

8. Mikus J, Steverding D. A simple colorimetric method to screen drug cytotoxicity against Leishmania using the dye Alamar Blue. Parasitol Int. 2000;48(3):265-269.

9. Rahman AA, Samoylenko V, Jacob MR, et al. Antiparasitic and antimicrobial indolizidines from the leaves of Prosopis glandulosa var. glandulosa. Planta Med. 2011;77(14):1639-1643.

10. Makler MT, Ries JM, Williams JA, et al. Parasite lactate dehydrogenase as an assay for Plasmodium falciparum drug sensitivity. Am JTrop Med Hyg. 1993;48(6):739-741.

11. National Committee for Clinical Laboratory Standards. Reference Method of Broth Dilution Antifungal Susceptibility Testing of Yeasts. Approved Standard, 2nd ed. Wayne, PA: National Committee for Clinical Laboratory Standards. 2002;22:1-51.
12. National Committee for Clinical Laboratory Standards. Methods for Dilution Antimicrobial Susceptibility Tests for Bacteria that Grow Aerobically. NCCLS Document M7-A5. Wayne, PA: National Committee for Clinical Laboratory Standards. 2000;20:1-58.

13. Kupchan SM, Karim A, Marcks C. Taxodione and taxodone, two novel diterpenoid quinone methide tumor inhibitors from Taxodium distichum. J Am Chem Soc. 1968;90(21):5923-5924.

14. Dellar JE, Core MD, Waterman PG. Antimicrobial abietane diterpenoids from Plectranthus elegans. Phytochemistry. 1995;41(3):735-738.

15. Ying BP, Kubo I. Complete proton and carbon-13 NMR assignments of totarol and its derivatives. Phytochemistry. 1991;30(6):1951-1955.

16. Samoylenko V, Dunbar DC, Gafur MA, et al. Antiparasitic, nematicidal and antifouling constituents from Juniperus berries. Phytother Res. 2008;22(12):1570-1576.

17. Machumi F, Samoylenko V. Yenesew A, et al. Antimicrobial abietane diterpenoids from the roots of Clerodendrum eriophyllum. Nat Prod Commun. 2010;5(6):853-858.

\section{Publish your work in this journal}

Research and Reports in Medicinal Chemistry is an international, peerreviewed, open access journal publishing original research, reports, reviews and commentaries on all areas of medicinal chemistry. The manuscript management system is completely online and includes a very quick and fair peer-review system, which is all easy to use.

\section{Dovepress}

Visit http://www.dovepress.com/testimonials.php to read real quotes from published authors. 